\title{
The Impact of Foreign Exchange Rate on the Balance of Trade in Jordan
}

\author{
Torki M. Al-Fawwaz
}

To Link this Article: http://dx.doi.org/10.6007/IJARAFMS/v11-i4/11694 DOI:10.6007/IJARAFMS /v11-i4/11694

Received: 18 October 2021, Revised: 20 November 2021, Accepted: 30 November 2021

Published Online: 17 December 2021

In-Text Citation: (Al-Fawwaz, 2021)

To Cite this Article: Al-Fawwaz, T. M. (2021). The Impact of Foreign Exchange Rate on the Balance of Trade in Jordan. International Journal of Academic Research in Accounting Finance and Management Sciences, 11(4), 57-70.

\section{Copyright: @ 2021 The Author(s)}

Published by Human Resource Management Academic Research Society (www.hrmars.com)

This article is published under the Creative Commons Attribution (CC BY 4.0) license. Anyone may reproduce, distribute, translate and create derivative works of this article (for both commercial and non-commercial purposes), subject to full attribution to the original publication and authors. The full terms of this license may be seen at: http://creativecommons.org/licences/by/4.0/legalcode

\section{Vol. 11, No. 4, 2021, Pg. 57 - 70}

Full Terms \& Conditions of access and use can be found at http://hrmars.com/index.php/pages/detail/publication-ethics 


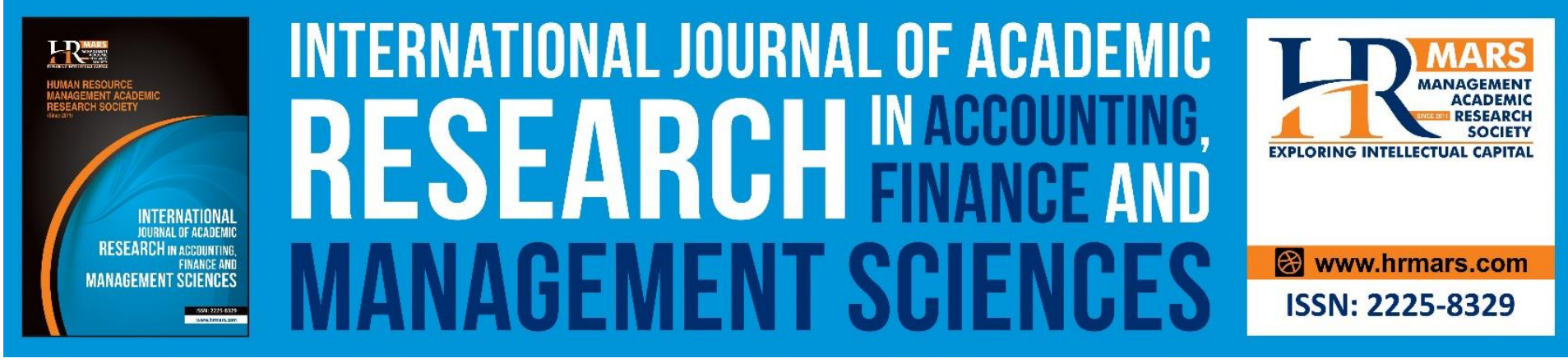

\title{
The Impact of Foreign Exchange Rate on the Balance of Trade in Jordan
}

\author{
Prof. Torki M. Al-Fawwaz \\ Al al-Bayt University. Faculty of economics and business administration, Finance and \\ Economic Dept \\ Email: alfawwaz@aabu.edu.jo
}

\begin{abstract}
"This work has been carried out during sabbatical leave granted to the author (Prof. Torki M Al-Fawwaz) from Al Al-Bayt University during the academic year 2020/2021"
\end{abstract}

\begin{abstract}
This study aimed to measure the impact of foreign exchange rate of each of the following currencies (real US dollar exchange rate, Sterling Pound exchange rate and Euro exchange rate) on balance of trade in Jordan during the period (1995-2019) through adopting the descriptive analytical approach using the Vector Error Correction Model (VECM). The results of the study revealed that foreign exchange rates have a strong impact on reducing the Jordanian trade balance deficit. The study recommended the need to promote national production by improving and diversifying the production base, not relying on one source of export, and finding other sources of income for the country.
\end{abstract}

Keywords: Trade Balance, Exchange Rate, VECM, Jordan.

\section{Introduction}

The trade balance reflects how a state deals with the outside world. Jordan, as other developing countries, suffers from numerous structural deficiencies as a result of lack of is economic and financial resources, weakness of its production base, its big dependence on imports and its little size of exports, which led to a continuous, permanent and chronic deficiency in its trade balance.

Commercial openness among the world's countries has led to an expansion of commercial exchange among many countries, which resulted in deficiencies in their balance of payments. Currency exchange rate has a great importance in affecting many economic variables, among which are the size of external trade and the status of trade balance of countries, noting that the exchange rate policy is one of the most important tools of monetary policy used to protect national economy from potential external shocks.

Exchange rate is considered among the total economic variables, being depended on by the world's countries for the sake of activating exports through its reduction and consequently increasing the competitiveness of local products. Many countries all over the world endeavored to adopt the policies of exchange rate fixation in the context of the recommendations of financial institutions and the International Monetary Fund, in order to 
MANAGEMENT SCIENCES

Vol. 11, No. 3, 2021, E-ISSN: 2225-8329 @ 2021 HRMARS

attract many investments and as an attempt by those countries to fight inflation and control the prices of goods and services, as well as to correct deficiencies in the trade balance.

\section{Study Problem}

The Jordanian economy suffers from a continuous deficiency in its trade balance, which reached (-8.92) billion JD in 2018 compared to (-7.59) billion JD in 2017 (Jordan's Central Bank, Annual report, 2018), as a result of weakness in production base, decrease in national exports and increase in the size of imports. Moreover, the Jordanian economy is impacted by the exchange rates of foreign currencies. As the imbalances that may occur in the exchange rate of any country reflect negatively on its economic performance, because the exchange rate has an impact on economic indicators, including the trade balance, and this is related to the state's productive capabilities that do not allow to meet the local demand of individuals in society without resorting to import, which The state must move towards trade openness to the world.

This study attempts to correct the deficiency in Jordanian trade balance, through answering the following question:

- What is the effect of foreign currency exchange rate represented in (the actual US dollar exchange rate, the Sterling Pound exchange rate and the Euro exchange rate) on the Jordanian trade balance during the period (1995-2019)?

\section{Study Objective}

The study mainly aims at measuring the effect of foreign currency exchange rates represented in (the actual US dollar exchange rate, the Sterling Pound exchange rate and the Euro exchange rate) on the Jordanian trade balance during the period (1995-2019).

\section{Study Importance}

A country's exchange rate represents a link between its economy and the economies of other countries as well as a measure of the size of the country's currency, because of its obvious and important effect on the balance of the country's total economy, either directly or indirectly, particularly through its connection to the country's trade balance and its reflection of the country's economic status, both internally and externally.

From here came the importance of the current study represented in measuring the effect of foreign currency exchange rates represented in (the actual US dollar exchange rate, the Sterling Pound exchange rate and the Euro exchange rate on the Jordanian trade balance.

\section{Study Hypothesis}

The study hypothesis is based on the non-existence of a statistically significant effect of foreign currency exchange rates represented in (the actual US dollar exchange rate, the Sterling Pound exchange rate and the Euro exchange rate) on the Jordanian trade balance at the significance level $(\propto \leq 0.05)$.

\section{First-Theoretical Framework}

\section{Exchange Rate: Concept and Importance}

The existence of external trade among countries through the processes of import and export requires the presence of an exchange rate between the currencies of each two countries; meaning the existence of a price of a country's currency evaluated by the prices of the 
MANAGEMENT SCIENCES

Vol. 11, No. 3, 2021, E-ISSN: 2225-8329 @ 2021 HRMARS

currencies of other countries, for the sake of estimating the prices of goods and services in the country, which is known as the foreign exchange rate.

\section{Latrash (2007:96) Defined the Exchange Rate as}

"The number of units of a certain currency that must be paid to obtain one unit of another currency". Awadallah (2004:44) defined it as "the price of one unit of a certain currency in the form of units of the national currency". However, other countries see that the exchange rate is the price of one unit of the national currency in the form of units of a certain foreign currency.

Baumol (1988:821) defined it as "the price of a unit of a foreign currency expressed in units of the local currency; or the price of a unit of the local currency expressed in units of a foreign currency. So, the exchange rate is the price or value of a currency expressed in another currency". According to the researcher's point of view, the exchange rate can be defined as a linking tool between the prices of goods or services in the local market and the prices of corresponding goods or services in the international market according to the forces of supply and demand.

The exchange rate realizes many economic goals, among which is the balance between internal and external economies, where the internal economic balance is represented in the stability of the prices of local goods and services and the achievement of a high economic growth, while the external economic balance is represented in the equilibrium of payments' balance.

\section{Types of Exchange Rate}

There are several forms and types of exchange rate; as follows

1- Nominal exchange rate: it is the price of foreign currency expressed in units of local currency with ignoring the currency's purchase power. Here, the inflation rate is not taken into account, which means that the exchange rate does not reflect the reality of the currency and can't be depended on in measuring market competitiveness among countries (Al-Abbas, 2003:3). It is divided into two types (Qaddi, 2003:103):

a- Official Exchange Rate: it is the price adopted pertinent to economic exchanges that officially occur among countries.

b- Exchange Rate in Parallel Markets: where there is more than one nominal exchange rate of the same currency at the same time for the same country.

2- Real Exchange Rate: it is the number of units of imported goods sufficient to purchase one unit of the local good; it reflects the country's ability to compete. It also measures the inflation rate, where when there exists a big difference between the nominal exchange rate and the real exchange rate, this means a high inflation rate (Joly et al., 1996:4). It can be calculated using the following formula:

$$
T C R=T C N \times \frac{P^{*}}{P}
$$

where: $T C R=$ real exchange rate;

$\mathrm{TCN}+$ nominal exchange rate;

$P^{*}=$ prices in the foreign country;

$\mathrm{P}=$ prices in the local country. 
MANAGEMENT SCIENCES

Vol. 11, No. 3, 2021, E-ISSN: 2225-8329 @ 2021 HRMARS

3- Actual Exchange Rate: it is an indicator that measures the mean of change in the exchange rate of the currency of a country compared with the currencies of other countries during a certain period. It indicates the development of the currency of a country in relation to a currency portfolio in a certain period of time (Oliveira and e-Castro, 2011:234).

4- Real Actual Exchange Rate: it is a nominal exchange rate that expresses the mean of a group of dual exchange rates. It is subject to correction through the removal of the effect of relative price changes (Al-Ghalibi, 2011:32).

5- Balance Exchange Rate: it is the price determined when the supply value of a currency is equal to its demand value, i.e., when the supply and demand powers are equal, irrespective of the effect of speculation, simultaneously with the equilibrium of the balance of payments (Al-Abbas, 2003:7).

\section{Trade Balance: Concept and Importance}

There are several definitions pertinent to the concept of trade balance. Abd Al-Nasser (2006:387) defined it as "the difference between the value of a country's exports and the value of its imports". Guartini and Strop (1999: 543) defined it as: "the credit of operations; i.e., purchases and sales of goods and services".

It can also be defined as the difference between the value of exports and that of imports of a country during a certain period and can be expressed as shown in the following formula:

\section{Trade Balance Credit $=$ Exports - Imports}

The trade balance forms the most significant part in a country's balance of payments. If a country's exports are more than its imports, there is a balance surplus or a commercial surplus. In contrast, if a country's exports are less than its imports, there is a commercial deficit.

The importance of trade balance lies in that it represents the most important and essential part in the balance of payments, since it shows the country's production activity. When there is a deficiency in the trade balance because of weakness in the country's production ability or its inability of meeting the economy's needs, the country then resorts to import and the expansion of its economic activity. Furthermore, the trade balance directly affects the currency value and the stock markets (Khalaf, 2004:234).

\section{Relationship between Exchange Rate and Trade Balance}

There is a strong relationship between the exchange rate of the currency of a country and its trade balance. When the value of a country's exports rises, the value of its currency rises as a result of increasing demand for it. Consequently, the prices of goods and services become high for foreigners, which leads to a decrease in demand for them, causing a disorder in the trade balance. Here, the country resorts to encourage import for the sake of returning to the balance state.

On the other hand, if the exchange rate of a country's currency is determined to be less than it should be, this leads to an increase in exports and a decrease in imports, which in turn causes a disorder in the country's trade balance, resulting in some inflation pressures that contribute to the continuation of this disorder. So, there is a proportional relationship between exchange rate and trade balance. When the size of exports increases, this leads to an enhancement in the trade balance and an increase in the reserves of foreign currencies of the exporting country (Yousef, 2010:79). 
MANAGEMENT SCIENCES

Vol. 11 , No. 3, 2021, E-ISSN: 2225-8329 @ 2021 HRMARS

\section{Second-Literature Review}

Al-Rqaibat and Al-Khaza'li (2018) conducted a study to show the types, policies and theories of exchange rate and its effect on the Jordanian balance of payments over the period (19902018) through clarifying the effect of each of (the French Frank, the Sterling Pound, the Japanese Yen and the German Mark) on the Jordanian trade balance, using the statistical analysis program STATA. The results revealed that the Jordanian balance of payments is positively affected by the exchange rates of the French Frank and Japanese Yen, resulting in reducing the size of deficiency in the trade balance, in addition to that the Jordanian balance of payments is negatively and harmfully affected by the Sterling Pound and the German Mark exchange rates, causing an increase in the deficiency in the balance of payments.

Kishk (2017) investigated the potential effect of lowering the Egyptian currency value on the trade balance, through studying the development of some variables of the Egyptian economy represented in (the development of exchange rates and the development of the size of exports and imports) over the period (2001-2016), using the descriptive analytical approach. The results showed a positive effect of the exchange rate on the Egyptian trade balance in the short term through enhancing the Egyptian exports and the slight deceleration of the growth of imports.

A study conducted by Doha (2014/2015) aimed at showing the impact of the exchange rate behavior on the equilibrium of trade balance and determining the efficiency extent of the exchange rate system in reducing the deficiency in the trade balance over the period (19902013), using the ordinary least squares (OLS) method. The findings of the study revealed a proportional relationship between exchange rate and trade balance credit, where an increase in the exchange rate of the Algerian dinar by one unit leads to a change in the trade balance credit by 1.35 units. Moreover, there is a proportional and statistically acceptable relationship between the developments of oil prices and the trade balance credit, where the change in oil prices by one unit leads to a change in the trade balance credit by 0.51 unit.

Ahmad et al (2014) conducted a study with the aim of determining the impact of exchange rate on the balance of payments of the Pakistani economy by using monthly data for the period (2007-2013), through applying Granger's test of causality and the auto-regression test for the distributed lag periods (ARDL). The results revealed the presence of a positive relationship between the exchange rate and the balance of payments. Consequently, the stability of exchange rate could create a positive environment through investment encouragement, which in turn enhances the balance of payments.

Umoru and Odjegba (2013) investigated the relationship between exchange rate disturbance and the balance of payments considering mis-adaptation in Nigeria over the period (19732012) using the vector error correction model (VECM). The results showed that exchange rate disturbance had a direct effect on the status of balance of payments in Nigeria. The findings of the Granger's causality test indicated the presence of a uni-directional causal relationship pointing from the exchange rate disturbance to the modification of balance of payments in Nigeria. The study recommended the Nigerian government to implement economic policies that could reinforce the estimation of the Nigerian exchange rate and the US exchange rate to obtain an appropriate equilibrium in the balance of payments. 
MANAGEMENT SCIENCES

Vol. 11, No. 3, 2021, E-ISSN: 2225-8329 @ 2021 HRMARS

Saqib and Sana (2012) attempted to point out the effect of fluctuations in exchange rate on the size of export trade in Pakistan during the period (1981-2010). The results showed an adverse impact of the effective real exchange rate on the size of Pakistani exports, while the imports are directly connected to the size of exports and positively affect the country's exports, where the country should increase exports rather than reducing imports.

Oladipupa and Onotaniyohuwo (2001) measured the impact of exchange rate on the balance of payments in Nigeria during the period (1970-2008) using the ordinary least squares (OLS) method. Exchange rate, amount of money circulated, real gross domestic product, inflation rate and general price level were used as independent variables. The results showed that lowering the exchange rate leads to enhance the balance of payments in Nigeria in light of financial discipline and that incorrect lowering, misuse of local credit, absence of financial discipline and lack of central of expenditures in the country lead to a continuous deficit in the balance of payments.

Obaseki (2009) conducted a study with the aim of clarifying the way of managing foreign exchange rate in Nigeria over the past, present, and future periods through introducing the structural adjustment program (SAP). The study revealed that no country can obtain foreign currencies through exporting goods and services, direct investment flow, external loans or aids and grants that can be used in the settlement of international commitments when there is an imbalance in the foreign exchange market as a result of insufficiency in the supply of foreign services, which may lead to pressure on foreign money reserves; and when the foreign reserves are not sufficient, this could deteriorate into problems in the balance of payments. Therefore, there is a need to manage the country's foreign money resources to reduce the negative effects of foreign exchange rate fluctuations.

Stucka (2004) studied the effect of exchange rate change on the trade balance in Croatia in the short and long terms using two measures for the effective real exchange rate, by applying the autoregressive distributed lag (ARDL) method. The results revealed that a (1\%) permanent consumption leads to the enhancement of trade balance by a percentage of $(0.94 \%-1.3 \%)$ over 2.5 years.

Boyd et al (2001) aimed at measuring the impact of real exchange rate on the balance of payments of eight developed countries that belong to the Organization of Economic Cooperation and Development (OECD), using the vector autoregressive distributed lag (VARDL) method. The study results showed that the reduction of local currency exchange rate is accompanied by an enhancement in the trade balance through reliance on the flexibility of exports and imports. There are many previous studies related to the subject of the study, which used different economic models to show the impact of the exchange rate on the trade balance. What distinguishes the current study from previous studies is its use of the Vector Error Correction Model (VECM) to show the impact of the foreign exchange rate (the real US dollar exchange rate, the British pound exchange rate, the euro exchange rate) on the Jordanian trade balance during the period 1995- 2019. Given the limitations of Jordanian studies on this subject despite its importance, and in view of the importance of the trade balance as an indicator of conditions and foreign relations with countries, the importance of foreign exchange rates in reducing the trade balance deficit, and knowledge of the mechanism of using exchange rates as it deals with a very important topic.

\section{Third-The Study's Applied Aspect}

It includes the study's standard model, the study's data sources, the preliminary tests and the study's model assessment. 


\section{The Standard Model}

The study model has been designed depending on previous studies associated with the impact of foreign exchange rate on trade balance, such as: Al-Rqaibat and Al-Khaza'li (2018); Oladipupa and Onotaniyohuwo (2011), where the following standard model has been formulated:

$\mathrm{TB}=f($ Dollar, Pound, Euro)

$$
\text { TB }_{t}=\beta_{0}+\beta_{1} \text { Dollar }_{t}+\beta_{2} \text { Pound }_{t}+\beta_{3} \text { Euro }_{t}+U_{t}
$$

where:

$\mathrm{TB}=$ deficiency in trade balance (in billion JD).

Dollar = real US dollar exchange rate.

Pound $=$ Sterling Pound exchange rate.

Euro = Euro exchange rate.

\section{Preliminary Statistical Tests}

A set of preliminary tests were carried out before assessing the study's model.

\section{Unit Root Test of Time Series Staticity}

Some study variables are characterized by non-staticity, which leads to the appearance of the problem of false regression. To test the time series staticity, the expanded augmented DickeyFuller (ADF) test was carried out in order to test the null hypothesis stating that the time series is non-static as well as the presence of the unit root. Table 1 shows the results.

Table 1. Expanded Dickey-Fuller Test

\begin{tabular}{|l|l|l|l|}
\hline Variable & t-statistics & t-critical at 5\% & \\
\hline \multirow{2}{*}{ TB } & -0.51 & -2.99 & Level \\
\cline { 2 - 3 } Dollar & -4.31 & -3.00 & $\mathrm{I}(1)$ \\
\hline \multirow{2}{*}{ Pound } & -0.53 & -2.99 & \multirow{2}{*}{$\mathrm{I}(1)$} \\
\cline { 2 - 3 } & -4.01 & -3.00 & \multirow{2}{*}{$\mathrm{I}(1)$} \\
\hline \multirow{2}{*}{ Euro } & -1.79 & -2.99 & \multirow{2}{*}{$\mathrm{I}(1)$} \\
\cline { 2 - 3 } & -6.18 & -3.00 & \\
\hline
\end{tabular}

The results in Table 1 revealed the non-staticity of the study variables at the level. When taking the first difference, all the study variables became static. So, the null hypothesis is rejected, and the alternative hypothesis is accepted, stating the staticity of the time series and the absence of unit root at the section at a significance level of $5 \%$.

\section{2-Lag Length Selection Test}

This test is conducted to determine the number of time lag periods in order to eliminate the problem of autocorrelation between errors (serial correlation), depending on a set of criteria; namely, Akaike Info Criterion (AIC), Hannan-Quinn (HQ), Schwarz Info Criterion (SIC), 
MANAGEMENT SCIENCES

Vol. 11, No. 3, 2021, E-ISSN: 2225-8329 @ 2021 HRMARS

Likelihood Ratio Test (LRT) and Final Prediction Error (FPE) Criterion (Lu, 2001). Table 2 illustrates the test results.

Table 2. Test of Determining the Number of Time Lag Periods

\begin{tabular}{|l|l|l|l|l|l|l|}
\hline Lag & LogL & LR & FPE & AIC & SC & HQ \\
\hline $\mathbf{0}$ & 7.631248 & NA & $8.57 e-06$ & -0.315761 & -0.118283 & -0.266096 \\
\hline $\mathbf{1}$ & 69.12908 & $96.25747^{*}$ & $1.69 \mathrm{e}-07^{*}$ & -4.272094 & $-3.284708^{*}$ & $-4.023769^{*}$ \\
\hline $\mathbf{2}$ & 84.16819 & 18.30848 & $2.13 e-07$ & $-4.188538^{*}$ & -2.411243 & -3.741553 \\
\hline
\end{tabular}

The results in Table 2 revealed that the optimal number of time lag periods for the study model is (2) according to Akaike Info Criterion (AIC).

\section{3-Co-inegration Test}

Johansen co-integration test (Johansen, 1995) was conducted, since all the study variables are static at the first difference I (1), in order to test the null hypothesis stating the existence of one vector or less of co-integration vectors. Table 3 shows the test results.

Table 3. Results of Johansen Co-integration Test

\begin{tabular}{|l|l|l|l|l|l|l|l|}
\hline $\begin{array}{l}\text { Hypothesized } \\
\text { No. of CE(s) }\end{array}$ & $\begin{array}{l}\text { Trace } \\
\text { statistic }\end{array}$ & $\begin{array}{l}\text { Critical } \\
\text { Value 5\% }\end{array}$ & Prob.** & $\begin{array}{l}\text { Hypothesized } \\
\text { No. of CE(s) }\end{array}$ & $\begin{array}{l}\text { Max- } \\
\text { Eigen }\end{array}$ & $\begin{array}{l}\text { Critical } \\
\text { Value 5\% }\end{array}$ & Prob.** \\
\hline None * & 79.82631 & 47.85613 & 0.0000 & None * & 42.50937 & 27.58434 & 0.0003 \\
\hline At most 1 * & 37.31694 & 29.79707 & 0.0056 & At most 1 * & 25.67576 & 21.13162 & 0.0107 \\
\hline At most 2 & 11.64118 & 15.49471 & 0.1750 & At most 2 & 11.47854 & 14.26460 & 0.1318 \\
\hline
\end{tabular}

The results in Table 3 showed the existence of two co-integration vectors in the study equation according to trace test and maximum eigenvalue test at a significance level of $5 \%$. So, the co-integration test results confirm the presence of a long-term integration relationship among the study variables.

\section{4-Granger Causality Test}

Engel and Granger's test of causality (Engel and Granger, 1987) was used to examine the nature and direction of the causal relationship among the study variables, as illustrated in Table 4.

Table 4. Causality Test Results

\begin{tabular}{|c|c|c|c|c|}
\hline Null Hypothesis & Obs. & F-statistics & Prob. & Decision \\
\hline $\begin{array}{l}\text { DOLLAR does not Granger Cause } \\
\text { TB }\end{array}$ & 23 & 0.07104 & 0.9746 & $\begin{array}{l}\text { No directional } \\
\text { relationship }\end{array}$ \\
\hline $\begin{array}{l}\text { TB does not Granger Cause } \\
\text { DOLLAR }\end{array}$ & 23 & 5.80512 & 0.0077 & $\begin{array}{l}\text { uni-directional } \\
\text { relationship }\end{array}$ \\
\hline POUND does not Granger Cause TB & 23 & 4.38448 & 0.0210 & \multirow{2}{*}{$\begin{array}{l}\text { two-directional } \\
\text { relationship }\end{array}$} \\
\hline TB does not Granger Cause POUND & 23 & 3.28693 & 0.0500 & \\
\hline EURO does not Granger Cause TB & 23 & 4.19909 & 0.0241 & $\begin{array}{l}\text { uni-directional } \\
\text { relationship }\end{array}$ \\
\hline
\end{tabular}




\begin{tabular}{|l|l|l|l|l|}
\hline TB does not Granger Cause EURO & 23 & 0.20280 & 0.8928 & $\begin{array}{l}\text { No directional } \\
\text { relationship }\end{array}$ \\
\hline
\end{tabular}

The results indicated the existence of a uni-directional causal relationship going from trade balance deficiency in the direction of real US dollar exchange rate, as well as the existence of a bi-directional causal relationship between Sterling Pound exchange rate and trade balance deficit, in addition to the presence of a uni-directional causal relationship pointing from Euro exchange rate to trade balance deficit.

\section{5-Equation Assessment}

The study model has been assessed using the error correction model (VECM), since all the study variables are static at the first difference in addition to the presence of co-integration among the study variables. Two main tools were used in the analysis; namely, variance decomposition analysis and impulse response function analysis.

\section{A- Variance Decomposition}

Variance decomposition was applied to the study model, where the following results were obtained (see Table 5).

Table 5. Variance Decomposition

\begin{tabular}{|l|l|l|l|l|}
\hline Period & TB & Dollar & Pound & Euro \\
\hline $\mathbf{1}$ & 100.0000 & 0.000000 & 0.000000 & 0.000000 \\
\hline $\mathbf{2}$ & 83.48495 & 0.621666 & 12.76502 & 3.128362 \\
\hline $\mathbf{3}$ & 74.99076 & 1.081987 & 13.57012 & 10.35714 \\
\hline $\mathbf{4}$ & 72.18439 & 2.632278 & 12.84328 & 12.34005 \\
\hline $\mathbf{5}$ & 72.72626 & 4.946605 & 11.88417 & 10.44297 \\
\hline
\end{tabular}

The results in Table 5 show that the Jordanian trade balance is affected by the real US dollar exchange rate, where during period 2 , the changes in the real US dollar exchange rate represented about (0.62) of the prediction in the Jordanian trade balance. This value tended to increase in the subsequent years to reach about (4.95) in period 5, which indicates that the real US dollar exchange rate affects the Jordanian trade balance with a time lag, meaning that the effect does not last only for one period of time, but continues for coming periods of time.

The results also show that the Jordanian trade balance is impacted by the Sterling Pound exchange rate. During period 2 , the changes in the Sterling Pound exchange rate represented about (12.77) of the prediction in the Jordanian trade balance. It is observed that this value tends to decrease in the subsequent years to reach about (11.88) in period 5, which indicates that the Sterling Pound exchange rate affects the Jordanian trade balance with a time lag, meaning that the effect is not restricted to one period of time, but extends to coming periods of time.

Furthermore, the findings reveal that the Jordanian trade balance is impacted by the Euro exchange rate. During period 2, the changes in the Euro exchange rate represented about (3.13) of the prediction in the Jordanian trade balance. It is noted that this value tends to increase in the subsequent years, reaching about (10.44) in period 5, which indicates that the Euro exchange rate affects the Jordanian trade balance with a time lag, meaning that the effect is not restricted to one period of time, but extends to coming periods of time.

\section{B- Impulse Response Function}


MANAGEMENT SCIENCES

Vol. 11, No. 3, 2021, E-ISSN: 2225-8329 @ 2021 HRMARS

Figure (1) illustrates the reaction response of the Jordanian trade balance to the exchange rates of some foreign currencies, represented in (the real US dollar exchange rate (Dollar), the Sterling Pound exchange rate (Pound) and the Euro exchange rate (Euro)).



Figure (1): Reaction Response of the Jordanian Trade Balance to Exchange Rate Changes of some Foreign Currencies

The results of reaction response function show that the real US dollar exchange rate has a positive impact on the Jordanian trade balance, where the increase in the real US dollar exchange rate leads to an increase and an enhancement in the Jordanian trade balance for a period of time extending to about 5 years.

On the other hand, the reaction response function results show that the Sterling Pound exchange rate has a negative impact on the Jordanian trade balance, where the increase in the Sterling Pound exchange rate leads to an increase and an enhancement in the Jordanian trade balance for a time period extending to two years, after which the impact begins to decrease.

Also, it was revealed that the Euro exchange rate has a positive impact on the Jordanian trade balance, where the increase in the Euro exchange rate leads to an increase and an enhancement in the Jordanian trade balance for a time period of about 3 years, after which the impact begins to decrease.

\section{Results and Recommendations}

This study aimed at investigating the impact of foreign exchange rate represented in (the real US dollar exchange rate, the Sterling Pound exchange rate and the Euro exchange rate) on the Jordanian trade balance during the period (1995-2019). The results obtained can be summarized as follows: 
MANAGEMENT SCIENCES

Vol. 11, No. 3, 2021, E-ISSN: 2225-8329 ๔ 2021 HRMARS

1- The extended Dickey-Fuller test results revealed the staticity of the study variables at the first difference I (1). Further, the Johansen co-integration test showed a long-term integration relationship among the study variables.

2- Granger's causality test indicated the presence of a uni-directional causal relationship going from the trade balance deficit in the direction of the real US dollar exchange rate, as well as the presence of a bi-directional causal relationship between the Sterling Pound exchange rate and the trade balance deficit, whereas there was a uni-directional causal relationship pointing from the Euro exchange rate to the trade balance deficit.

3- Variance decomposition analysis showed that the Jordanian trade balance is affected by the real US dollar exchange rate, where during period 2, the changes in the real US dollar exchange rate represented about (0.62) of the prediction in the Jordanian trade balance. It was observed that this value tended to increase in the subsequent years to reach about (4.95) in period 5, meaning that the real US dollar exchange rate impacts the Jordanian trade balance with a time lag. The reaction response function results showed that the real US dollar exchange rate has a positive impact on the Jordanian trade balance, where the increase of the real US dollar exchange rate leads to an increase and an enhancement in the value of trade balance for a period of time extending to 5 years. This result agrees with the results obtained by Kishk (2017); Doha (2014/2015), while it contradicts with the results obtained by (Saqib and Sana, 2012; Oladipupa and Onotaniyohuwo, 2011).

4- The variance decomposition analysis results showed that the Jordanian trade balance is affected by the Sterling Pound exchange rate, where during period 2, the changes in the Sterling Pound exchange rate represented about (12.77) of the prediction in the Jordanian trade balance. It is observed that this value tends to decrease in the subsequent years to reach about (11.88) in period 5, which indicates that the Sterling Pound exchange rate affects the Jordanian trade balance with a time lag; not only for one period of time, but for coming time periods. The reaction response function results revealed a negative impact of the Sterling Pound exchange rate on the Jordanian trade balance, where the increase of the Sterling Pound exchange rate leads to an increase and an enhancement in the trade balance for a time period extending to two years, after which the effect begins to decrease. This is in agreement with the results obtained by Kishk (2017) and Doha (2014/2015), while it contradicts with the results of Al-Rqaibat and Al-Khaza'li (2018).

5- The variance decomposition analysis results showed that the Jordanian trade balance is affected by the Euro exchange rate, where during period 2, the changes in the Euro exchange rate represented about (3.13) of the prediction in the Jordanian trade balance. It is observed that this value tends to increase in the subsequent years to reach about (10.44) in period 5, which indicates that the Euro exchange rate affects the Jordanian trade balance with a time lag; not only for one period of time, but for coming time periods.

The reaction response function results revealed a positive impact of the Euro exchange rate on the Jordanian trade balance, where the increase of the Euro exchange rate leads to an increase and an enhancement in the Jordanian trade balance for a time period extending to 3 years, after which the impact begins to decrease.

This result is in agreement with the results obtained by Kishk (2017) and Doha (2014/2015). According to the study results, the following recommendations are presented:

1- Reinforcing the national production through enhancing and diversifying the production basis, as well as refraining from depending on one export product or destination, in addition to finding other income sources for the country. 
MANAGEMENT SCIENCES

Vol. 11, No. 3, 2021, E-ISSN: 2225-8329 @ 2021 HRMARS

2- Diversifying the export structure and lowering imports, particularly oil imports, in addition to developing the production structure.

3- Attracting foreign investments for the sake of obtaining capital, as well as pumping various exportable products in the local market with the aim of improving the Jordanian trade balance.

4- Lowering the value of imports through encouraging local production, supporting small and medium enterprises (SMEs) and raising productivity.

\section{References}

Abd Al-Nasser, J. (2006). Economic Lexicon. Osama House for Publishing and Distribution, Jordan.

Ahmad, N., Ahmed, R., Khoso, I., Palwishah, R., \& Raza, U. (2014). Impact of Exchange Rate on Balance of Payment: An Investigation from Pakistan. Research Journal of Finance and Accounting, 5 (13), 32-42.

Al-Abbas, B. (2003). Policies of Exchange Rates. A Periodic Series Concerned with Development Issues in Arab Countries, Kuwait.

Al-Ghaleby, A. Al-H. J. (2011). Exchange Rate and Its Management in Light of Economic Shocks (Theories and Applications). Safa'a House for Publishing and Distribution, Jordan.

Abd A-Majid, Al-R, G., \& Al-Khaza'li, A. S. (2018). Effect of Jordanian Dinar Exchange Rate with Foreign Currencies on the Jordanian Balance of Payments over the Period (1990-2015). Arab Journal of Management, 38 (3).

Awadhallah, Z. H. (2004). International Economy. New University House, Al-Azaritah.

Baumol, W. J. (1988). Economic Principle Policy. Seventh Edition, Dryden Press, New York University.

Boyd, D., Caporale, G. M., \& Smith, R. (2001). Real Exchange Rate Effects on the Balance of Trade: Co-integration and the Marshall-Lerner Condition. International Journal of Finance and Economics, 6 (3), 187-200.

Doha, S. (2014/2015). Impact of Exchange Rate Fluctuations on the Trade Balance and Methods of Remedy: Case Study of Algeria. PhD Thesis, Department of Commercial Sciences, Faculty of Economic, Commercial and Administrative Sciences, Mohammad Khaider University Biskara, Algeria.

Engel, R. F., \& Granger, C. W. J. (1987). Co-integration and Error Correction: Representation, Estimation and Testing. Econometrics. 55 (2), 251-276.

Guartini, J., \& Strop, R. (1999). Total Economy: General and Special Choice. Mars House for Publishing, First Edition.

Johnston, J., \& Dinardo, J. (1995). Econometric Methods. The McGraw-Hill Companies, Inc., Tokyo.

Joly, H., Prigent, C., \& Sobczak, N. (1996). La taux de change réel déquilibre: Une Introduction. Ministere de l'economie et des Finances, PARIS, 4.

Khalaf, F. H. (2004). International Economic Relations. Al-Warraq Establishment for Publishing and Distribution, First Edition, Jordan.

Kisk, M. Abd Al-W. (2017). Lowering Exchange Rate and Its Impact on Egyptian Trade Balance. Scientific Journal of the Sector of Commercial Colleges, Al-Azhar University, (17).

Latrash, Al-T. (2007). Techniques of Banks. University Printings House, Sixth Edition, Algeria.

Laza'r, A., \& Ayet, Y. S. (2012). Real Actual Exchange Rate and the Algerian Economy's Competitiveness. The Researcher's Journal, Warqala University, Algeria, (11). 
Lu, D. (2011). Augmented Dickey - Fuller Test and the Lag Length Selection Problem. Central University of Finance \& Economics Journal, Beijing, China, 130-134, 3019-3022.

Obaseki, P. J. (2009). Foreign Exchange Management in Nigeria: Past, Present and Future. CBN Economic and Financial Review, 29 (1).

Oladipupa, A. O., \& Onotaniyohuwo, F. O. (2011). Impact of Exchange Rate on Balance of Payment in Nigeria. African Research Review: An International Multidisciplinary Journal, 5 (21), 73-88.

Oliveira, J. Z., \& e-Castro, M. F. (2011). Mapping a Country's Competitive Position: A Real Exchange Rate Approach. Studies in Economics and Finance, Emerald Group Publishing, 28 (3), 223-244.

Qaddi, A. Al-M. (2003). Introduction to Total Economic Policies: An Analytical Evaluative Study. University Printings House, Algeria.

Yousef, T. A. Al-R. (2010). International Financial Administration and Transacting with Foreign Currencies. Safa'a House for Publishing and Distribution, Jordan.

Saqib, N., \& Sana, I. (2012). Exchange Rate Volatility and Its Effect on Pakistan's Export Volume. Advances in Management and Applied Economics, 2 (4), 109-124.

Stucka, T. (2004). The Effect of Exchange Rate Change on the Trade Balance in Croatia. IMF Working Paper.

Umora, D., \& Odjegba, O. P. (2013). Exchange Rate Misalignment and Balance of Payment Adjustment in Nigeria. European Scientific Journal, 9 (13), 261-273. 